Edisi Januari - Juni 2020 Vol 19 No 1

\section{JURNAL ILMU PEMERINTAHAN}

\section{nakhoda}

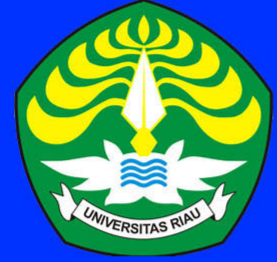

Innovation Hub: Media Kolaborasi Menuju Pemerintahan Daerah Inovatif Herie Saksono

Institusional Building dalam Mengatasi Persoalan Pertambangan Emas Tanpa Izin Di Kabupaten Kuantan Singingi Provinsi Riau

Khotami

Gerakan Masyarakat Tertib Administrasi Kependudukan Melalui Inovasi Pelayanan Lukadesi (Keluarga Berduka Desa Siaga)

Di Kabupaten Sleman D.I Yogyakarta

Hendy Setiawan, Fariza Ikhsanditya

Provinsi 'Istimewa Melayu Riau Kepulauan'

Muchid Albintani, Auradian Marta

Kaderisasi dan Penetapan Calon Legislatif pada Partai Politik (Studi DPD Partai Nasional Demokrat Seram Bagian Barat 2019)

Fandi Ahmad Sintani, Wahab Tuanaya, Marno Wance

Factors of Affect Deliberation of Maguwoharjo

Village Development Planing Sub-District Depok Regency Sleman Yogyakarta Muhammad Rafi, Ulung Pribadi, Fajar Rahmanto

Survey Kepuasan Masyarakat (SKM) pada Badan PendapatanDaerah Kabupaten Bintan

Suherry, Billy Jenawi, Rendra Setyadiharja,

Zamzami A Karim, Firman Setyawan, Rany Angraini

Peran Dewan Perwakilan Daerah (DPD) dalam

Pembentukan Daerah Otonomi Baru (DOB) Di wilayah Provinsi Maluku Utara

Abdul Halil Ibrahim, Bakri La Suhu, Rifjal Tifandy, Marno Wance

MEDIA INFORMASI DAN KOMUNIKASI ILMIAH CIVITAS AKADEMIKA JURUSAN ILMU PEMERINTAHAN

FAKULTAS ILMU SOSIAL DAN ILMU POLITIK

UNIVERSITAS RIAU
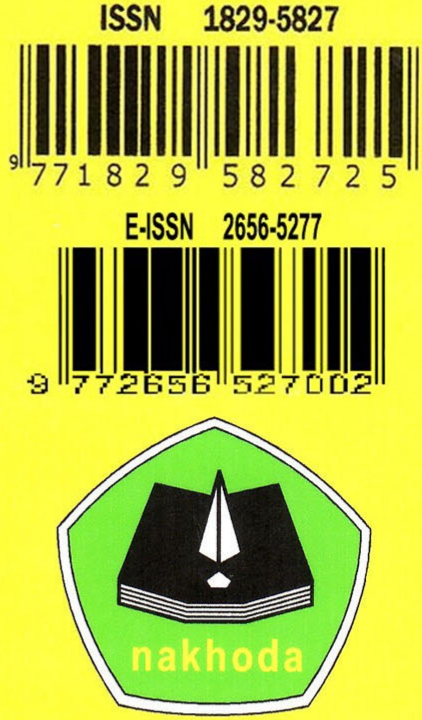

DITERBITKAN OLEH :

LABORATORIUM ILMU PEMERINTAHAN
SEKRETARIAT :

KAMPUS BINA WIDYA SIMPANG BARU

PANAM KM. 12,5 PEKANBARU

(28293) Telp/Fax. (0761)63277 
NAKHODA:

JURNAL

ILMU PEMERINTAHAN
NAKHODA: JURNAL ILMU PEMERINTAHAN

Edisi Januari - Juni 2020 Volume: 19 Nomor: 1

ISSN : 1829-5827 | E-ISSN : 2656-5277

DOI : https://doi.org/10.35967/jipn

https://nakhoda.ejournal.unri.ac.id/index.php/JIPN

INNOVATION HUB: MEDIA KOLABORASI MENUJU PEMERINTAHAN DAERAH INOVATIF

Herie Saksono

Badan Penelitian dan Pengembangan (BPP) Kementerian Dalam Negeri, Jakarta, Indonesia

$1-16$

INSTITUTION BUILDING DALAM MENGATASI PERSOALAN PERTAMBANGAN EMAS

TANPA IZIN DI KABUPATEN KUANTAN SINGINGI PROVINSI RIAU

Khotami

Program Studi Ilmu Pemerintahan, Fakultas IImu Sosial dan IImu Politik Universitas Islam Riau. 17 - 37

Pekanbaru-Indonesia

GERAKAN MASYARAKAT TERTIB ADMINISTRASI KEPENDUDUKAN MELALUI INOVASI

PELAYANAN LUKADESI (KELUARGA BERDUKA DESA SIAGA) DI KABUPATEN SLEMAN

D.I. YOGYAKARTA

Hendy Setiawan ${ }^{1}$, Fariza Ikhsanditya ${ }^{2}$

1,2 Departemen IImu Pemerintahan, Universitas Muhammadiyah Yogyakarta, Yogyakarta,

Indonesia

PROVINSI “ISTIMEWA MELAYU KEPULAUAN RIAU” (GAGASAN PERMULAAN)

Muchid Albintani', Auradian Marta ${ }^{2}$

1,2 Jurusan IImu Pemerintahan, Fakultas IImu Sosial dan IImu Politik, Universitas Riau

KADERISASI DAN PENETAPAN CALON LEGISLATIF PADA PARTAI POLITIK (Studi DPD

Partai Nasional Demokrat Seram Bagian Barat 2019

Fandi Ahmad Sintani ${ }^{1}$, Wahab Tuanaya ${ }^{2}$, Marno Wance ${ }^{3}$

1,2,3 Jurusan IImu Pemerintahan, Universitas Pattimura, Indonesia

$75-90$

FACTORS THAT AFFECT DELIBERATION OF MAGUWOHARJO VILLAGE DEVELOPMENT

PLANNING SUB-DISTRICT DEPOK REGENCY SLEMAN YOGYAKARTA

Muhammad Rafi ${ }^{1}$, Ulung Pribadi2, Fajar Rahmanto ${ }^{3}$

1,2,3 Department of Government Affairs and Administration, Universitas Muhammadiyah

Yogyakarta, Indonesia

SURVEY KEPUASAN MASYARAKAT (SKM) PADA BADAN PENDAPATAN DAERAH

KABUPATEN BINTAN

Suherry ${ }^{1}$, Billy Jenawi², Rendra Setyadihardja ${ }^{3}$, Zamzami A. Karim4,

Firman Setiawan ${ }^{5}$, Rany Angraini ${ }^{6}$

$102-112$

1,2,3,4 STISIPOL Raja Haji, Tanjungpinang, Indonesia

5,6 Bapelitbang, Bintan, Indonesia

PERAN DEWAN PERWAKILAN DAERAH (DPD) DALAM PEMBENTUKAN DAERAH

OTONOMI BARU (DOB) DI WILAYAH PROVINSI MALUKU UTARA

Abdulhalil Hi. Ibrahim ${ }^{1}$, Bakri La Suhu2, Rifjal Tifandy 3 Marno Wance 4

1,2,3 IImu Pemerintahan Universitas Muhammadiyah Maluku Utara, Kota Ternate, Indonesia

$113-127$

${ }^{4}$ IImu Pemerintahan, Universitas Pattimura, Kota Ambon, Indonesia 


\title{
GERAKAN MASYARAKAT TERTIB ADMINISTRASI KEPENDUDUKAN MELALUI INOVASI PELAYANAN LUKADESI (KELUARGA BERDUKA DESA SIAGA) DI KABUPATEN SLEMAN D.I. YOGYAKARTA
}

\author{
Hendy Setiawan ${ }^{1}$, Fariza Ikhsanditya ${ }^{2}$ \\ ${ }^{1,2}$ Departemen Ilmu Pemerintahan, Universitas Muhammadiyah Yogyakarta, Yogyakarta, Indonesia \\ hendysetiawan357@gmail.com
}

\begin{abstract}
ABSTRAK
Penelitian ini menganalisis gerakan masyarakat tertib administrasi kependudukan di Kabupaten Sleman melalui inovasi pelayanan Lukadesi dengan alat analisis teori proses inovasi De Jong dan Den Hartog yakni melihat peluang, mengeluarkan ide, mengkaji ide, dan implementasi. Rendahnya kesadaran masyarakat Sleman akan administrasi kependudukan di bidang kematian menjadi perhatian yang serius. Hal ini dikarenakan ketika terjadi peristiwa kematian masyarakat enggan melaporkan ke pihak terkait sehingga data kependudukan yang ada di database tidak sesuai dengan jumlah masyarakat di lapangan. Semenjak dibentuknya inovasi Lukadesi justru keadaan berubah drastis, di mana dengan pelayanan Lukadesi masyarakat sangat partisipatif. Hasil menunjukkan bahwa inovasi Lukadesi menjadi layanan unggulan desa yang dibentuk pada pertengahan 2017 dan sampai saat ini sudah 83 desa dari 86 desa yang ada di Kabupaten Sleman menjadi peserta Lukadesi. Inovasi ini mampu menumbuhkan kesadaran administrasi kematian masyarakat di Kabupaten Sleman yang mencapai $90 \%$ lebih, sehingga data yang ada pada database kependudukan Dinas Kependudukan dan Pencatatan Sipil lebih akurat dibandingkan sebelum adanya inovasi Lukadesi. Metode penelitian ini menggunakan kualitatif deskriptif dengan teknik pengumpulan data dengan cara wawancara dan observasi. Kesimpulanya ialah gerakan inovasi Lukadesi telah memenuhi tahapan proses inovasi dengan tingkat partisipasi dan respon publik yang sangat prestisius.
\end{abstract}

Kata Kunci: Administrasi Kependudukan, Inovasi Pelayanan Publik, Lukadesi

\section{PENDAHULUAN}

Persoalan pelayanan publik merupakan aspek yang harus segera dibenahi. Hal tersebut menjadi penting karena dalam sektor pelayanan memegang peranan penting dalam penyelenggaraan pemerintahan. Di Indonesia sektor pelayanan publik masih memiliki banyak catatan yang sangat kompleks yang harus dibenahi oleh pemerintah. Situasi saat ini pemerintah sebagai penyedia pelayanan publik baik itu sebagai penyedia barang publik atau penyedia jasa publik nyatanya sampai saat ini masih memiliki masalah yang sangat kompleks melihat kebutuhan masyarakat warga negara yang sangat beragam dan diiringi oleh kebutuhan pelayanan publik yang semakin kompleks pula. Pelayanan publik yang sedang berlangsung di Indonesia sampai saat ini masih belum dapat dikatakan memuaskan karena masih banyak proses pelayanan publik yang berbelit-belit, diskriminasi, mahal dari sisi pembiayaan sehingga 
dilihat dari aspek manapun pelayanan publik di Indonesia belum memberikan kepuasan pelayanan kepada warga negaranya (Putra, 2018). Berdasarkan kondisi pelayanan publik tersebut maka pemerintah dituntut untuk melakukan berbagai langkah yang jitu untuk mengupayakan agar pelayanan publik yang diberikan lebih maju, transparan, akuntabel, dan yang paling ditekankan adalah aspek kualitas pelayanan publik yang lebih baik lagi (Ariyani dkk, 2016). Melihat proses pelayanan publik di Indonesia masih banyak persoalanpersoalan yang belum dapat diselesaikan dengan baik, oleh karenanya dalam aspek peningkatan pelayanan publik memerlukan cara cara yang kreatif dan inovatif yang harus dilekatkan dalam sektor pelayanan publik (Anggraeny, 2013:85). Hal ini menjadi sangat penting mengingat langkah kreatif dan inovatif dalam pelayanan publik menjadi terobosan baru agar mampu meningkatkan kualitas pelayanan publik di Indonesia.

Dwidowidjoto

mengemukakan bahwa organisasi publik memiliki peranan yang sangat dominan dalam menentukan kualitas pelayanan publik yang diimplementasikan oleh suatu birokrasi. Artinya bahwa semakin rendah kinerja organisasi publik maka secara otomatis juga akan semakin buruk kualitas pelayanan yang akan diberikan. Hal tersebut memberikan implikasi yang sangat kompleks jika kinerja organisasi publik buruk, pasalnya ketika kualitas pelayanan yang dicapai buruk berarti mereka gagal di dalam memberikan informasi, data, dan alternatif yang baik di dalam proses formulasi kebijakan, dan akibatnya pelayanan yang diberikanpun tidak akan dapat optimal. Sebaliknya, jika kinerja organisasi publik bagus maka secara otomatis pula kualitas pelayanan yang dihasilkan juga akan semakin baik.

Oleh karena itu kebobrokan sektor pelayan memerlukan sebuah inovasi pelayanan yang baik. Inovasi menjadi stimulus untuk memperbaiki kinerja pelayanan publik. Sesuai dengan penelitian yang dilakukan oleh Mindarti (2018) terkait dengan inovasi pelayanan kesehatan terhadap gerakan serentak keluarga siaga (Gertak Kasi) oleh Puskesmas Bades Kecamatan Pasirian Kabupaten Lumajang , di mana inovasi tersebut mampu menurunkan Angka Kematian Bayi (AKB). Inovasi ini berupa sebuah program di mana dalam implementasinya ada beberapa alur yang harus dilakukan seperti adanya pelatihan keluarga siaga, adanya monitoring hasil pelatihan dengan cara mengunjungi rumah masyarakat dan juga adanya pelayanan pembuatan akta kelahiran secara gratis, mudah dan cepat.oleh karena itu inovasi menjadi langkah mendesak agar permasalahan pelayanan publik yang tengah dialami selama ini dapat diselesaikan.

Guna merespon permasalahan tersebut melalui Peraturan Menteri Pendayagunaan Aparatur Negara dan Reformasi Birokrasi Nomor 9 Tahun 2015 tentang Inovasi Pelayanan Publik maka berbagai instansi pemerintah baik di tingkat pusat atapun daerah gencar menciptakan terobosan-terobosan baru melalui inovasi dalam pelayanan. Salah satu instansi yang menciptakan inovasi tersebut adalah instansi di Dinas Kependudukan dan Pencatatan Sipil Kabupaten Sleman D.I. Yogyakarta melalui inovasi pelayanan publik bernama 
"Lukadesi (Keluarga Berduka Desa Siaga). Inovasi pelayanan publik Lukadesi ini merupakan salah satu cara yang dilakukan oleh Dinas Kependudukan dan Pencatatan Sipil Kabupaten Sleman untuk mewujudkan masyarakat Kabupaten Sleman yang tertib adminitrasi kependudukan. Hal ini dikarenakan masih banyaknya masyarakat yang belum sadar administrasi kependudukan misalnya dalam saat terjadi kematian.
Banyak kejadian kematian dari anggota masyarakat yang tidak melaporkan sehingga data kependudukan yang ada di database tidak sesuai di lapangan. Setelah muncul inovasi Lukadesi ini terjadi peningkatan masyarakat terhadap kesadaran adminitrasi terkait dengan peristiwa kematian. Hal ini dibuktikan dengan data yang dirilis oleh Dinas Kependudukan dan Pencatatan Kabupaten Sleman sebagai berikut.

Tabel 1 Presentase Kepemilikan Kutipan Akte Kematian Kabupaten Sleman Uraian Perubahan Inovasi Peningkatan

Tahun

\begin{tabular}{|c|c|c|c|c|c|}
\hline & & 2017 & 2018 & Jumlah & $\%$ \\
\hline \multirow{2}{*}{$\begin{array}{c}\text { Permohonan Akta } \\
\text { Kelahiran }\end{array}$} & Rutin & 2799 & 5100 & 3201 & 82,21 \\
\hline & Terlambat & 6782 & 8103 & 1321 & 19,48 \\
\hline \multicolumn{2}{|c|}{ Total } & 9581 & 13.203 & 3622 & 37,80 \\
\hline
\end{tabular}

Sumber: Data Dukcapil Sleman 2018

Berdasarkan data di atas terjadi peningkatan presentase kepemilikan kutipan akte kematian di Kabupaten Sleman dalam kurun waktu 2017-2018. Data tersebut dikarenakan adanya inovasi Lukadesi memberikan dampak yang sangat signifikan terhadap administrasi kematian.
Hal tersebut dikuatkan dengan data cakupan penerbitan kutipan akta kematian sebelum dan sesudah adanya inovasi Lukadesi di Kabupaten Sleman antara tahun 2013 sampai tahun 2018 dapat dilihat dari data di bawah ini.

Tabel 2 Cakupan Penerbitan Akte Kematian Sebelum dan Sesudah Inovasi Lukadesi di Kabupaten Sleman

\begin{tabular}{ccccc}
\hline No & Tahun & Jumlah Kematian & Dicarikan Akte Kematian & Presentase \\
\hline 1 & 2013 & 4414 & 3876 & $87,81 \%$ \\
\hline 2 & 2014 & 4985 & 4416 & $88,59 \%$ \\
\hline 3 & 2015 & 3747 & 3291 & $87,83 \%$ \\
\hline 4 & 2016 & 5233 & 3054 & $66,83 \%$ \\
\hline 5 & 2017 & 6059 & 4214 & $69,55 \%$ \\
\hline 6 & 2018 & 6744 & 6108 & $90,56 \%$ \\
\hline
\end{tabular}


Selain itu inovasi ini muncul sebagai sebuah bentuk gebrakan kreatif inisiatif dalam pelayanan publik guna mendukung surat intruksi dari Pemerintah Pusat melalui Kementerian Dalam Negeri tanggal 7 Februari 2018 tentang Gerakan Indonesia Sadar Adminitrasi atau sering disebut GISA. Intruksi ini ditujukan kepada Pemerintah Daerah baik Provinsi ataupun Kabupaten/Kota di Indonesia agar tercipta iklim adminitrasi yang tertib, tertata, dan teratur. Menghadapi persoalan tersebut maka dibentuklah suatu layanan publik yang lebih inovatif dan kreatif yakni melalui inovasi pelayanan publik Lukadesi "Keluarga Berduka Desa Siaga" yang dalam realisasinya mengoptimalkan data kematian dengan mengintegrasikan data secara berjenjang (Dinas Kependudukan dan Pencatatan Sipil Kabupaten Sleman dengan Desa). Inovasi Lukadesi ini menjadi satu-satunya inovasi di wilayah Yogyakarta yang mampu menumbuhkan kesadaran masyarakat terhadap pentingnya masyarakat yang sadar adminitrasi kependudukan.

Berdasarkan permasalahan pelayanan publik yang telah diuraikan di atas, maka perlu dilakukan penelitian dengan judul "Gerakan Masyarakat Tertib Administrasi Kependudukan Melalui Inovasi Pelayanan Lukadesi (Keluarga Berduka Desa Siaga) di Kabupaten Sleman D.I. Yogyakarta". Inovasi ini menjadi satusatunya inovasi yang ada di Indonesia dibidang penerbitan kutipan akta kematian dengan waktu yang sangat cepat dan tepat sehingga banyak daerah lain yang melakukan studi banding terkait inovasi yang ada di Kabupaten Sleman ini. Tujuan dari penelitian ini ialah untuk menggali lebih dalam pelaksananan gerakan masyarakat tertib administrasi di bidang kematian melali inovasi Lukadesi, sehingga rumusan masalah dari riset ini ialah bagaimana pelaksanaan program gerakan masyarakat tertib administrasi kependudukan melalui inovasi Lukadesi di Kabupaten Sleman?

\section{KERANGKA TEORI}

Menurut De Jong dan Den Hartog (dalam Djamrut, 2015:1478-1479) memberikan argumen jika tahapan atau proses inovasi terdiri dari empat bagian, di mana antar bagian tersebut saling berkaitan dan memiliki korelasi yang kuat. Oleh karena itu elemen-elemen tersebut harus saling terintegrasi secara utuh jika sebuah pelayanan telah memenuhi tahapan proses inovasi. Empat tahapan inovasi tersebut meliputi:

\section{Melihat Peluang}

Inovasi harus dapat muncul ketika terjadi masalah. Adanya kesenjangan antara apa yang seharusnya dengan realita yang terjadi justru mampu memunculkan peluang yang inovatif atau perilaku solutif. Artinya bahwa hadirnya sebuah inovasi pelayanan bukan hal yang mengada ada akan tetapi dengan segala pertimbangan yang ada inovasi mampu membawa nilainilai kebaharuan di mana dalam setiap nilai kebaharuan tersebut mengandung nilai kemanfaatan dan kegunaan dalam pelayanan. Inovasi diciptakan dengan melihat persoalan yang dihadapi sehingga dengan adanya inovasi dalam sektor layanan mampu mengurai masalah yang tengah dihadapi. Oleh karena itu, maka inovasi yang baik ialah harus mampu memberikan dampak yang positif terhadap perbaikan-perbaikan dalam bidang 
pelayanan sehingga meningkatkan kualitas pelayanan publik. Bukan sebaliknya, dengan adanya inovasi justru menambah tingkat kompleksitas persoalan yang tengah dihadapi.

\section{Mengeluarkan Ide}

Artinya bahwa ketika menghadapi masalah atau jalan buntu justru membuat seseorang baik individu, kelompok, ataupun organisasi mampu mengeluarkan ide-ide inovatif sebanyak mungkin sehingga pada akhirnya ide tersebut menjadi langkah kreatif dan inovatif dalam menghadapi persoalan yang muncul. Oleh karena itu peranan organisasi publik sangat penting untuk mampu merumuskan ide atau gagasan yang solutif dalam mengatasi situasi kebuntuan yang dihadapinya. Ketika organisasi publik ini gagal dalam merumuskan ide dan gagasan maka yang terjadi justru masalah tersebut akan menjadi lebih kompleks ketika tidak segera diatasi secara bijak. Oleh karenanya seberapa cepat tanggapnya organisasi publik akan menentukan keberhasilan dalam merumuskan ide tersebut.

\section{Mengkaji Ide}

Maksudnya bahwa tidak semua ideide yang muncul dapat diimplementasikan. Oleh karena itu perlu filterisasi dan pengerucutan ide yang memungkinkan untuk bisa diterapkan dan dikomparasikan antara yang satu dengan yang lainya terhadap besar kecilnya manfaat ketika ide itu diimplementasikan. Ide yang muncul tentunya dikaji secara sistematis dan mendalam apakah ide gagasan yang ada jika diterapkan dapat mengurai persoalan yang ada. Pada intinya ide tersebut sebelum diimplementasikan di tengah- tengah masyarakat sudah mampu diuji keakuratanya atau dalam istilah yang dikenalkan oleh Roggers (2003) sebagai triability (kemungkinan dicoba) atau lebih tepatnya uji publik. Oleh karenanya pada proses inilah tempat memastikan layak atau tidaknya sebuah ide jika digunakan terhadap penyelesaian persoalan yang dihadapinya. Pada tahap ini perlu pertimbangan mendalam terhadap dampak baik maupun buruknya sehingga stelelah dinyatakan layak maka ide tersebut dapat diimplementasikan sebagai upaya menuntaskan masalah yang ada.

\section{Implementasi}

Artinya bahwa ide yang sudah terpilih langsung diimplementasikan dengan berani mengambil risiko yang ditimbulkan. Risiko dalam berinovasi berkorelasi dengan kemungkinan sebuah inovasi itu gagal atapun kemungkinan inovasi itu akan berhasil. Tentu saja di dalam tahap imlementasi ini menjadi bagian dari tahap proses inovasi yang terakhir dengan penuh optimistic mampu membawa perubahan tingkat kepuasan pelayanan disektor publik sehingga masyarakat sebagai penerima layanan merasakan pelayanan yang meringankan baik dari berbagai aspek. Pada tahap implementasi inilah sebuah masyarakat akan mampu menilai kinerja organisasi publik di dalam memformulasikan kebijakan inovasi yang diambil. Selain itu, pada tahap ini publik akan melihat apakah gagasan yang dipilih dan diimplementasikan akan mengalami keberhasilan atau justru mengalami kegagalan.

Oleh karenanya tahap implementasi ini sangat menentukan kualitas kinerja 
organisasi publik di dalam menformulasikan sebuah inovasi disektor publik secara jelas apakah memang organisasi publik memiliki kinerja yang berorientasi untuk memudahkan layanan serta mencari terobosan baru di dalam mereka melayani masyarakat secara masif.

Konsep tahapan atau proses inovasi di atas sangat relevan untuk mengkaji gerakan masyarakat tertib administrasi di Kabupaten Sleman melalui inovasi Lukadesi apakah keberhasilan dari inovasi pelayanan Lukadesi ini memenuhi unsurunsur tahapan proses inovasi tersebut atau apakah ada salah satu unsur yang tidak terpenuhi sehingga ini menjadi temuan baru jika keberhasilan inovasi Lukadesi Kabupaten Sleman tersebut tidak memenuhi salah satu unsur proses inovasi pelayanan publik.

\section{METODE PENELITIAN}

Penelitian ini menggunakan pendekatan deskriptif kualitatif. Menurut Bungin (dalam Wulandari dkk 2017:67) mengutarakan bahwa metode kualitatif deskriptif yaitu peneliti berusaha merekontruksi atau mendeskripsikan hasil wawancara secara mendalam terhadap sasaran yang akan diteliti atau objek penelitian. Penelitian ini dilaksanakan di Kabupaten Sleman tepatnya di Dinas Kependudukan dan Pencatatan Sipil Kabupaten Sleman. Jenis data yang akan dikumpulkan dalam penelitian ini adalah data primer dan data sekunder. Data primer dalam penelitian ini adalah semua informasi mengenai Inovasi Pelayanan Publik Lukadesi (Keluarga Berduka, Desa Siaga) di Dinas Kependudukan dan Pencatatan Sipil Kabupaten Sleman melalui dokumentasi dan wawancara.
Penelitian ini mewawancarai setidaknya 8 orang narasumber yakni Kepala Bidang Kependudukan dan Pencatatan Sipil Kabupaten Sleman yakni Ibu Maya Dra Mayawati Jati Lestari, M.T, Bapak Dukuh Sidokarto yakni Bapak Suryanto, Ibu Krismi Nurhayati selaku petugas register kependudukan desa, Fariza selaku ketua komunitas pemerhati pelayanan. Selain itu peneliti dalam menganalisis data secara kualitatif menggunakan teorinya Miles dan Huberman (dalam Masdy dkk, 2017:86) di mana dijelaskan jika dalam mengolah data kualitatif dapat dilakukan dengan menggunakan tiga tahap, yakni tahap reduksi, penyajian data, dan terakhir penarikan kesimpulan.

\section{HASIL DAN PEMBAHASAN}

A. Potret Gerakan Masyarakat Sadar Administrasi Kependudukan Dalam Bingkai Inovasi Lukadesi

Lahirnya inovasi gerakan masyarakat tertib administrasi kependudukan dimulai dari sebuah gerakan dari masyarakat desa yang dipelopori oleh Desa Wukirsari Kecamatan Cangkringan Kabupaten Sleman D.I. Yogyakarta. Hal tersebut berangkat dari persoalan yang dialami oleh masyarakat, di mana ketika terjadi peristiwa kematian maka mereka enggan melaporkan kasus kematian yang terjadi. Masalah tersebut sangat wajar, karena masyarakat yang mengalami duka kematian tidak sempat mengurus surat administrasi kematian karena mereka sudah disibukkan dengan prosesi kematian sampai ke pemakaman. Berawal dari persoalan tersebut, maka kompleksitas masalah akan semakin banyak ditingkat pemerintah baik pusat maupun daerah. Ketika masyarakat tidak melaporkan 
kematianya ke pihak yang bersangkutan, misalnya tidak melapor ke Dinas Kependudukan dan Pencatatan Sipil setempat maka nama mereka yang telah meninggal akan tetap ada dalam database Dinas Kependudukan dan Pencatatan Sipil. Akibatnya adalah terjadi ketidak absahan data yang dimiliki Dinas Kependudukan dan Pencatatan Sipil terhadap jumlah masyarakat yang ada di lapangan.

Permasalahan akan semakin kompleks ketika data yang ada di database Dinas Kependudukan dan Pencatatan Sipil diadopsi oleh baik itu KPU/KPUD untuk keperluan penetapan hasil DPT (Daftar Pemilih Tetap). Implikasinya dari data yang tidak sesuai tadi ialah munculnya pemilih hantu yakni pemilih yang namanya tercantum di DPT akan tetapi orang yang bersangkutan sudah meninggal. Oleh karena itu maka terjadi ketidak akuaratan data kependudukan yang dimiliki Dinas Kependudukan dan Pencatatan Sipil.

Tabel 3. Rendahnya Laporan Administrasi Kematian Masyarakat Pada Kurun 2016-2017

\begin{tabular}{cccc}
\hline Tahun & $\begin{array}{c}\text { Jumlah } \\
\text { Kematian }\end{array}$ & $\begin{array}{c}\text { Dicarika } \\
\text { n Akta } \\
\text { Kematian }\end{array}$ & Presentase \\
\hline 2016 & 5233 & 3054 & $66,83 \%$ \\
2017 & 6059 & 4214 & $69,55 \%$ \\
$\mathbf{2 0 1 8}$ & $\mathbf{6 7 4 4}$ & $\mathbf{6 1 0 8}$ & $\mathbf{9 0 , 5 6 \%}$ \\
\hline
\end{tabular}

Sumber: LAKIP Kabupaten Sleman 2018

Berdasarkan data yang disajikan pada tabel di atas maka dapat dipahami bahwa hadirnya inovasi pelayanan Lukadesi mampu memicu pergerakan data yang sangat signifikan, di mana hambir terjadi kenaikan laporan administrasi kematian sebesar $30 \%$. Artinya bahwa
Lukadesi menjadi model pelayanan yang diinisiasi Desa Wukirsari Cangkringan pada pertengahan tahun 2017 sekarang sukses diimplementasikan di Kabupaten Sleman. Inovasi ini menjadi satu satunya inovasi dalam bidang kematian yang ada di Indonesia sehingga banyak pemerintah daerah yang melakukan studi banding dan mengadopsi inovasi ini untuk diterapkan di daerahnya masing-masing.

Inovasi dalam pelayanan publik menjadi sebuah langkah yang harus diwujudkan, pasalnya dengan inovasi dapat meningkatkan kualitas kinerja pelayanan dan dapat memberikan kepuasan pelayanan kepada publik sehingga munculnya inovasi tersebut mampu memperbaiki kekurangan-kekurangan, memodifikasi sesuatu yanag lama menjadi sesuatu yang bisa memberikan manfaat masyarakat secara masif dan terstruktur (Peyusinta dan Setyawan, 2019). Sementara itu dalam inovasi di sektor pelayanan publik yang paling terpenting ialah difusi inovasi atau penyebaranya. Maksudnya bahwa inovasi yang bagus memiliki kemampuan untuk mudah diterima oleh masyarakat umum dan masyarakat merespon secara aktif dari adanya inovasi tersebut, dan dengan demikian secara tidak langsung inovasi tersebut telah dikenalkan oleh pemerintah kepada publik dengan tujuan untuk memperbaiki kekurangan sebelumnya.

Sebuah inovasi yang dihadirkan harus mampu mengubah keadaan kualitas pelayanan publik yang lebih baik lagi, bukan menambah keresahan masyarakat sebagai pengguna layanan publik (Bambang dalam Maulana, 2018). Hal tersebut tergambar dari tingginya partisipasi pelayanan Lukadesi yang 
mampu mengikutkan 96\% desa-desa di Kabupaten Sleman sebagai peserta pelayanan gerakan masyarakat tertib administrasi melalui Lukadesi.

\section{B. Analisis Tahapan/Proses Inovasi Gerakan Masyarakat Sadar Administrasi Kependudukan Dalam Konsep Inovasi Lukadesi}

Inovasi dalam sektor pelayanan publik khususnya dalam meningkatkan kualitas pelayanan jika ditelusuri lebih jauh baru mendapat perhatian ketika munculnya kebijakan otonomi daerah dengan dikeluarkanya regulasi yakni Undang-Undang Nomor 22 tahun 1999 tentang Pemerintah Daerah. Diimplementasikanya Undang-Undang Nomor 22 tahun 1999 tentang Pemerintah Daerah tersebut memberikan implikasi yang sangat besar terhadap struktur dan tata pamong penyelenggaraan Pemerintah Daerah (Maulana, 2018). Adanya transformasi dari sektor pelayanan ini sebagai respon dari tuntutan publik yang begitu masif terjadi. Transformasi ini ditandai adanya pergeseran konsep dari sentralisasi ke konsep desentralisasi.

Menurut Adeliya dalam Maulana (2018) mengutarakan bahwa pergeseran konsep sentralisasi ke desentralisasi pada dasarnya menjadi pintu masuk dan membuka ruang kesempatan kepada Pemerintah Daerah untuk mampu menjawab tuntutan publik dalam sektor pelayanan publik menggunakan cara-cara inovatif dengan terobosan yang baru serta memacu Pemerintah Daerah untuk terus berdaya cipta yang kreatif dan inovatif di sektor pelayanan publik.

Oleh karena itu keberadaan inovasi dalam sektor publik menjadi sangat penting, pasalnya dalam sektor publik harus mampu menyesuaikan dengan kebutuhan publik. Terkait dengan hal tersebut maka perlu dilakukan penelitian terkait inovasi yang ada di Kabupaten Sleman yakni gerakan masyarakat tertib administrasi kependudukan melalui inovasi pelayanan publik Lukadesi guna mewujudkan Kabupaten Sleman tertib administrasi kependudukan pada level nasional. Pada penelitian ini, peneliti menggunakan teori yang dikemukakan oleh De Jong dan Den Hartog bahwa sebuah inovasi harus melewati empat tahapan proses dalam inovasi agar sebuah inovasi dapat diterima publik dan memiliki tingkat keberhasilan yang maksimal. Keempat tahapan proses inovasi menurut De Jong dan Den Hartog meliputi melihat peluang, mengeluarkan ide, mengkaji ide, dan implementasi. Semua tersebut merupakan satu kesatuan yang saling berkaitan erat.

\section{Melihat Peluang}

Inovasi dalam sektor publik pada subtansinya tidak muncul begitu saja akan tetapi, sebuah inovasi muncul karena ada peluang atapun celah sehingga sebuah inovasi tersebut mampu diimplementasikan. Persoalan yang muncul dalam sektor pelayanan publik menjadi alasan yang kuat itulah mengapa keberadaan inovasi adalah sebuah keharusan untuk memotong rantai pelayanan yang berbelit-belit, mahal dari aspek pembiayaan, dan lama dari sisi waktunya (Hisbani dkk, 2017:268). Seperti halnya dengan inovasi gerakan masyarakat tertib administrasi kependudukan melalui inovasi pelayanan Lukadesi. Inovasi lahir dilatarbelakangi oleh keresahan 
masyarakat dan pemerintah setempat yang melihat bahwa pelayanan administrasi kependudukan dalam bidang kematian masih jauh dari harapan. Banyaknya masyarakat yang belum sadar akan pentingnya administrasi kependudukan dikhawatirkan akan menurunkan kredibilitas kinerja organisasi publik setempat dalam menciptakan Kabupaten Sleman sebagai kabupaten tertib administrasi kependudukan.

Pada mulanya dibentuknya pelayanan Lukadesi yang dirintis pada tahun pertengahan 2017 didasari pada suatu kondisi di mana dalam menerbitkan kutipan akta kematian sangat membebani masyarakat yang mengalami duka kematian. Di sisi lain, mengurus administrasi kematian menjadi kewajiban bagi masyarakat agar data mereka yang sudah meninggal terhapus dari database kependudukan. oleh karena itu sangat tidak memungkinkan jika pada saat yang sama seorang masyarakat yang mengalami duka kematian harus melakukan dua hal yakni mengurus administrasi kematian saudaranya dan juga mengurus prosesi upacara jenazah dan pemakamanya.

Berangkat dari persoalan tersebut maka Desa Wukirsari melihat bahwa bagaimana caranya agar masyarakat yang mengalami duka yang disibukkan dengan mengurus jenazah anggota keluarganya tidak dibebani oleh adminstrasi kematianya. Oleha karenanya pada saat itu Pemerintah Desa Wukirsari Kecamatan Cangkringan membuat terobosan kebijakan dengan mengeluarkan surat kutipan akta kematian pada tingkat desa dan itupun diserahkan sebelum jenazah itu dimakamkan. Artinya bahwa kutipan akta kematian yang bersangkutan akan diserah terimakan kepada anggota keluarganya saat upacara pemberangkatan pemakaman.

Melihat peluang kesempatan tersebut maka inovasi tersebut dinaikkan levelnya pada tingkat kabupaten hingga akhirnya pada akhir tahun 2018 gerakan masyarakat tertib administrasi kependudukan mampu menambah peserta Lukadesinya menjadi berkembang ke Desa Sukoharjo, Desa Sinduarjo, dan Desa Tlogoadi. Jumlah peserta Lukadesi tersebut terus meningkat sehinggga ini menjadi kesempatan yang menguntungkan bagi masyarakat dan pemerintah untuk segera memasifkan jangkauan dari layanan Lukadesi tersebut.

Oleh karena itu dengan gambaran partisipasi masyarakat yang merespon dengan baik adanya inovasi layanan Lukadesi ini maka hal ini menjadi hal yang sangat mendesak untuk ditindaklanjuti oleh pihak terkait dengan tujuan untuk meningkatkan ketertiban administrasi kependudukan dari masyarakat agar dalam masyarakat tercipta budaya tertib administrasi kepndudukan dalam bidang kutipan akta kematian.

\section{Mengeluarkan Ide}

Pada tahap ini baik individu, kelompok, ataupun organisasi publik dituntut mampu memformulasikan sebuah kebijakan yang kreatif dan inovatif dalam merespon persoalan yang tengah dihadapi. Pada konteks ini, Lukadesi menjadi salah satu alternative inovasi yang digunakan untuk menciptakan budaya ketertiban admi istrasi kependudukan masyarakat dibidang kematian sehingga persoalan data yang ada didatabase kependudukan yang awalnya tidak valid maka melalui pelayanan 
Lukadesi ini dapat diminimalisisr sehingga data yang dimiliki Dinas Kependududkan dan Pencatatan Sipil adalah data yang akurat dan mampu dipertanggungjawabkan kepada publik. Oleh karenanya di dalam mengeluarkan gagasan Lukadesi ini direspon dengan baik oleh seluruh masyarakat Kabupaten Sleman. Hal ini dikarenakan dalam pelayanan kematian sistem Lukadesi ini tidak memakan waktu yang lama bahkan dalam sehari surat akta kematian dapat diterbitkan dengan cepat.

Keringanan dan kemudahan yang handal dalam sistem pelayanan ini membuat pelayanan kutiapan akta kematian menjadi pelayanan unggulan di Sleman dengan partisispasi masyarakat yang sangat luar biasa. Hal ini dibuktikan dengan waktu layanan yang sangat cepat dan murah sehingga sehari Dinas Kependudukan dan Pencatatan Sipil bisa menerbitkan surat kutipan akta kematian masyarakat yang bersangkutan.

\section{Tabel 5. Jenis Pelayanan dan Waktu} Penyelesaian Penerbitan Kutipan Akta Kematian

\begin{tabular}{clc}
\hline No & \multicolumn{1}{c}{ Jenis Pelayanan } & Waktu \\
\hline $\mathbf{1}$ & $\begin{array}{l}\text { Pengajuan berkas permohonan pencatatan } \\
\text { kematian }\end{array}$ & 2 Menit \\
\hline $\mathbf{2}$ & $\begin{array}{l}\text { Verifikasi dan validasi data dan informasi } \\
\text { dalam berkas permohonan akta kematian }\end{array}$ & 10 Menit \\
\hline $\mathbf{3}$ & $\begin{array}{l}\text { Penomoran dan pencatatan dalam register } \\
\text { akta kematian }\end{array}$ & 2 Menit \\
\hline $\mathbf{4}$ & $\begin{array}{l}\text { Penerbitan kutipan akta kematian } \\
\text { P }\end{array}$ & $\begin{array}{l}\text { Penghapusan biodata penduduk yang } \\
\text { meninggal }\end{array}$ \\
\hline $\mathbf{6}$ & $\begin{array}{l}\text { Penerbitan Kartu Keluarga (KK) dan } \\
\text { KTPel }\end{array}$ & 10 Menit \\
\hline $\mathbf{7}$ & $\begin{array}{l}\text { Penandatanganan dan pengesahan oleh } \\
\text { Kepala Dinas: a. Register akta kematian } \\
\text { b. Kutipan akta kematian c. Kartu } \\
\text { Keluarga (KK) }\end{array}$ & \\
\hline
\end{tabular}

8 Pemberian stempel dinas pada kutipan 3 Menit akta kematian dan Kartu Keluarga (KK)

9 Penulisan di buku register pengambilan 3 Menit dan penyerahan

Sumber: SOP Akta Kematian Disdukcapil

Sleman, 2019

Berdasarkan tabel di atas dapat dipahami bahwa di dalam menerbitak surat kutipan akata kematian dapat diproses secara efektif dan efisien. Hal tersebut menjadi dasar dalam pelayanan inovasi Lukadesi yang sesuai dengan keinginan dan kebutuhan masyarakat di mana publik akan selalu menuntut dan menginginkan atas pelayanan yang ringan, mudah, dan tidak berbelit-belit. Sepanjang masyarakat yang berduka telah memenuhi persyarakat dokumen seperti surat lelayu dari Kepala duku, fotokopi KK, Fotokopi KTP yang bersangkutan, dan akte kelahiran maka data tersebut akan diproses ke tingkat desa yang ditangani oleh petugas register kependudukan desa. Setelah data tersebut dinyatakan lengkap melalui aplikasi SIDAMPAK Kabupaten Sleman maka akan segera ditindaklanjuti dan diproses untuk penerbitanya. Oleh karenanya inovasi ini menjadi sangat terkenal di Kabupaten Sleman karena petugas baik dari Perangkat Desa atau pihak dari Dinas terkait akan secara langsung menyerahkan surat kutipan akata kematian tersebut sebelum dimakamkan.

\section{Mengkaji Ide}

Perintisan inovasi pelayanan publik Lukadesi di Sleman sudah melewati kajian yang mendalam sebelum diimplentasikan. Meminjam istilah yang dikemukakan oleh Roggers bahwa inovasi sebelum diimplementasikan harus melewati alaur 
yakni triability atau sering disebut sebagai uji publik. Hadirnya inovasi tersebut dalam prosesnya mampu memberikan solusisolusi bagi persoalan sebelumnya, sehingga dengan diimplementasikan inovasi tersebut mengikis persoalan lama yang masih menghambat dalam pelayanan publik. Inovasi pelayanan publik telah mengalami uji coba dan teruji yakni penerapan pertama kali dilakukan di Desa Wukirsari Cangkringan Sleman Yogyakarta. Desa ini dinobatkan sebagai pilot project Lukadesi di Kabupaten Sleman yang mana sampai saat ini sudah 83 desa dari 86 yang telah tergabung dalam inovasi pelayanan Lukadesi. Dinas Kependudukan dan Pencatatan Sipil melalui Desa Wukirsari Cangkringan Sleman mengangkat inovasi ini ke level Kabupaten sehingga saat ini Lukadesi menjadi pelayanan unggulan desa. Proses perjalananya dari pelayanan Lukadesi ini melewati proses yang sangat panjang, dari hanya satu desa, berkembang lagi pada akhir tahun 2017 yakni Desa Sukoharjo, Desa Sinduarjo dan Desa Tlogoadi hingga tahun 2018 oleh Dinas Kependudukan dan Pencatatan Sipil dimasifkan lagi agar seluruh desa tergabung dengan pelayanan Lukadesi. Pada akhirnya ini terus meningkat hingga sekarang desa yang ada di Kabupaten Sleman 96\% sudah tergabung dalam layanan Lukadesi.

\section{Gambar 1. Penyerahan Surat Kutipan Akta Kematian}

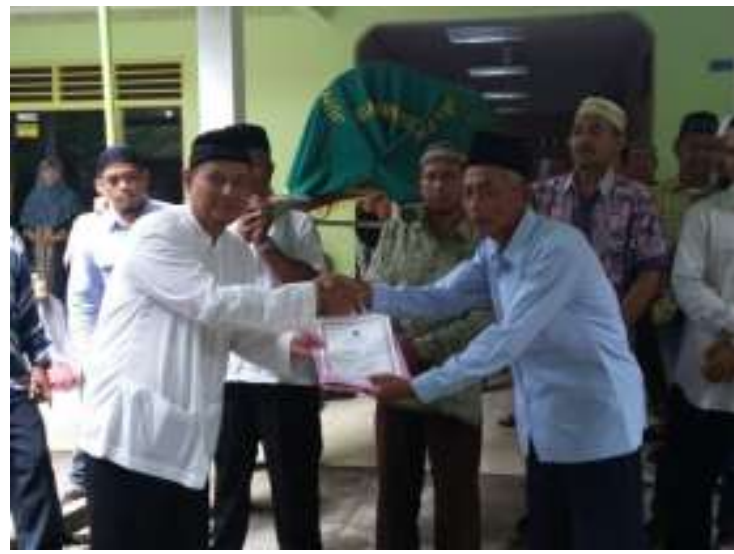

Mengacu pada gampar di atas sudah sangat jelas jika didalam pelayan publik keluarga berduka desa siahga Kabupaten Sleman menjadi inovasi layanan yang pertama di Indonesia dan satu-satunya yang ada dengan menerbitkan kutipan akta kematian yang cepat guna memacu ketertiban administrasi kependudukan khususnya dalam bidang kematian sehingga mampu menciptaka masyarakat yang sadar dan tertib administrasi kependudukan secara sistematis dan menyeluruh. Oleh karenanya inovasi ini ditengah-tengah keberhasilanya teah melewati tahap kajian gagasan Lukadesi yang mendalam dengan tanpa meninggalkan konsep pelayanan yang sebelumnya. Artinya, inovasi ini telah membawa nilai nilai kebaharuan yang lebih baik sehingga mampu berimplikasi pada manfaat yang dihasilkan oleh inovasi pelayanan ini.

\section{Implementasi}

Pada tahap implementasi inovasi pelayanan ini berjalan sesuai dengan 
NAKHODA: JURNAL ILMU PEMERINTAHAN

Edisi Januari-Juni Tahun 2020 Volume: 19 Nomor: 1

ISSN : 1829-5827 | E-ISSN : 2656-5277

DOI : https://doi.org/10.35967/jipn

https://nakhoda.ejournal.unri.ac.id/index.php/JIPN

konsep yang telah direncanakan. tujuan yang diharapkan dengan diciptakanya pelayanan Lukadesi ini nampaknya sukses didapatkan. Keakuratan data yang mampu dipertanggungjawabkan, kepuasan masyarakat yang semakin tinggi, mengindikasikan bahwa masyarakat merasa tidak terbebani dalam pelayanan ini. Hal ini dibuktikan dengan jangkauan dari peserta Lukadesi Kabupaten Sleman yang sampai saat ini sudah hampir seluruh masyarakat desa terlibat aktif dalam mendukung ketertiban administrasi.

Tabel 6. Desa Peserta Lukadesi Dinas Kependudukan dan Pencatatan Sipil Kabupaten Sleman

\begin{tabular}{|c|c|c|c|}
\hline \multirow[t]{2}{*}{ No } & \multirow[t]{2}{*}{ Kecamatan } & \multicolumn{2}{|c|}{ Lukadesi } \\
\hline & & Sudah & Belum \\
\hline 1 & Gamping & $\begin{array}{l}\text { 1. Ambarketawang } \\
\text { 2. Balecatur } \\
\text { 3. Banyuraden } \\
\text { 4. Nogotirto } \\
\text { 5. Trihanggo }\end{array}$ & - \\
\hline 2 & Godean & $\begin{array}{l}\text { 6. Sidorejo } \\
\text { 7. Sidokarto } \\
\text { 8. Sidoarum } \\
\text { 9. Sidoluhur } \\
\text { 10. Sidomulyo } \\
\text { 11. Sidoagung } \\
\text { 12. Sidomoyo }\end{array}$ & - \\
\hline 3 & Moyudan & $\begin{array}{l}\text { 13. Sumberrahayu } \\
\text { 14. Sumberagung } \\
\text { 15. Sumberarum } \\
\text { 16. Sumbersari }\end{array}$ & - \\
\hline 4 & Minggir & $\begin{array}{l}\text { 17. Sendangarum } \\
\text { 18. Sendangmulyo } \\
\text { 19. Sendangagung } \\
\text { 20. Sendangsari } \\
\text { 21. Sendangrejo }\end{array}$ & - \\
\hline 5 & Seyegan & $\begin{array}{l}\text { 22. Margoluwih } \\
\text { 23. Margokaton } \\
\text { 24. Margomulyo } \\
\text { 25. Margoagung } \\
\text { 26. Margodadi }\end{array}$ & - \\
\hline
\end{tabular}


ILMU PEMERINTAHAN
NAKHODA: JURNAL ILMU PEMERINTAHAN

Edisi Januari-Juni Tahun 2020 Volume: 19 Nomor: 1

ISSN : 1829-5827 | E-ISSN : 2656-5277

DOI : https://doi.org/10.35967/jipn

https://nakhoda.ejournal.unri.ac.id/index.php/JIPN

\begin{tabular}{|c|c|c|c|}
\hline 6 & Mlati & $\begin{array}{l}\text { 27. Sinduadi } \\
\text { 28. Sendangadi } \\
\text { 29. Tlogoadi } \\
\text { 30. Tirtoadi } \\
\text { 31. Sumberadi }\end{array}$ & - \\
\hline 7 & Depok & $\begin{array}{l}\text { 32. Caturtunggal } \\
\text { 33. Condongcatur } \\
\text { 34. Maguwoharjo }\end{array}$ & - \\
\hline 8 & Berbah & $\begin{array}{l}\text { 35. Sendangtirto } \\
\text { 36. Kalitirto } \\
\text { 37. Tegaltirto } \\
\text { 38. Jogotirto }\end{array}$ & - \\
\hline 9 & Prambanan & $\begin{array}{l}\text { 39. Wukirharjo } \\
\text { 40. Madurejo } \\
\text { 41. Sumberharjo } \\
\text { 42. Bokoharjo } \\
\text { 43. Gayamharjo } \\
\text { 44. Sambirejo }\end{array}$ & - \\
\hline 10 & Kalasan & $\begin{array}{l}\text { 45. Purwomartani } \\
\text { 46. Tirtomartani } \\
\text { 47. Selomartani }\end{array}$ & 1. Tamanmartani \\
\hline 11 & Ngemplak & $\begin{array}{l}\text { 48. Sindumartani } \\
\text { 49. Bimomartani } \\
\text { 50. Widodomartani } \\
\text { 51. Wedomartani } \\
\text { 52. Umbulmartani }\end{array}$ & - \\
\hline 12 & Ngaglik & $\begin{array}{l}\text { 53. Sariharjo } \\
\text { 54. Sinduharjo } \\
\text { 55. Sukoharjo } \\
\text { 56. Donoharjo } \\
\text { 57. Sardonoharjo }\end{array}$ & 2. Minomartani \\
\hline 13 & Sleman & $\begin{array}{l}\text { 58. Caturharjo } \\
\text { 59. Triharjo } \\
\text { 60. Tridadi } \\
\text { 61. Pandowoharjo } \\
\text { 62. Trimulyo }\end{array}$ & - \\
\hline
\end{tabular}


in NAKHODA:

JURNAL

ILMU PEMERINTAHAN
NAKHODA: JURNAL ILMU PEMERINTAHAN

Edisi Januari-Juni Tahun 2020 Volume: 19 Nomor: 1

ISSN : 1829-5827 | E-ISSN : 2656-5277

DOI : https://doi.org/10.35967/jipn

https://nakhoda.ejournal.unri.ac.id/index.php/JIPN

\begin{tabular}{|c|c|c|c|}
\hline 14 & Tempel & $\begin{array}{l}\text { 63. Banyurejo } \\
\text { 64. Tambakrejo } \\
\text { 65. Sumberrejo } \\
\text { 66. Pondokrejo } \\
\text { 67. Mororejo } \\
\text { 68. Margorejo } \\
\text { 69. Lumbungrejo } \\
\text { 70. Merdikorejo }\end{array}$ & - \\
\hline 15 & Turi & $\begin{array}{l}\text { 71. Donokerto } \\
\text { 72. Wonokerto } \\
\text { 73. Bangunkerto } \\
\text { 74. Girikerto }\end{array}$ & - \\
\hline 16 & Pakem & $\begin{array}{l}\text { 75. Candibinangun } \\
\text { 76. Hargobinangun } \\
\text { 77. Purwobinangun } \\
\text { 78. Harjobinangun }\end{array}$ & 3. Pakembinangun \\
\hline 17 & Cangkringan & $\begin{array}{l}\text { 79. Argomulyo } \\
\text { 80. Wukirsari } \\
\text { 81. Kepuharjo } \\
\text { 82. Umbulharjo } \\
\text { 83. Glagaharjo }\end{array}$ & - \\
\hline
\end{tabular}

Sumber: Dukcapil Sleman, 2019

Tingginya partisipasi masyarat dalam implementasi Lukadesi di atas maka menunjukkan bahwa masyarakat Kabupaten Sleman memiliki tingkat kesadaran administrasi kependudukan khususnya dalam bidang kematian. Inovasi pelayanan publik Lukadesi sudah menjawab masalah yang selama masyarakat alami. Masyarakat membutuhkan pelayanan yang cepat, mudah, dan biaya yang murah. Dilihat dari aspek sosialisasi dari inovasi ini maka dapat dikatakan kalau inovasi Lukadesi ini cukup berhasil, karena tanpa dilakukan sosialisasi yang masif masyarakat sudah banyak mengetahui. Berdasarkan jumlah desa yang ada di Kabupaten Sleman yakni 86 Desa maka 83 Desa sudah tergabung dalam inovasi Lukadesi. Hal ini menunjukkan bahwa aspek implementasi sudah terpenuhi dengan baik dari aspek keadaan masyarakat, kondisi masyarakat, dan juga sosialisasi dari bawah sendiri.

C. Sinergitas Pemerintah Daerah, Pemerintah Desa, dan Masyarakat Dalam Inovasi Lukadesi

Gerakan masyarakat sadar administrasi kependudukan melalui inovasi Lukadesi tidak lepas dari peran berbagai stakeholder. Sinergitas Pemerintah Daerah, Pemerintah Desa, dan Masyarakat menjadi kunci keberhasilan program ini. Hal ini sesuai dengan konsep yang disampaikan oleh Balogh (dalam Febrian, 2016) bahwa Collaborative Governance menjadi pendekatan yang kontruktif dengan melibatkan berbagai aktor. Menurutnya 
collaborative governance dimaknai sebagai rangkaian proses dan struktur dalam mengelola dan memformulasikan keputusan dalam kebijakan publik yang melibatkan aktor-aktor yang secara tertata dan terencana yang berasal dari berbagai level, baik dalam tataran pemerintahan dan atau lembagai publik, institusi swasta dan masyarakat sipil dalam rangka mencapai tujuan publik yang tidak dapat dicapai apabila dilaksanakan oleh satu pihak saja. Oleh karena itu terkait dengan sinergitas ketiga komponen tersebut dalam melaksanakan program inovasi Lukadesi Sleman dapat dipahami sebagai berikut:

Pertama, keterlibatan masyarakat dalam gerakan inovasi pelayanan publik Lukadesi Kabupaten Sleman. Sesuai dengan yang diutarakan oleh Ulfa (2018) yang mengemukakan argument jika dalam konsep collaborative governance masyarakat sebagai aktor non pemerintah yang menjadi kunci keberhasilan dalam pelaksanaan pelayanan publik. Sudah tidak disangkal kembali jika pelayanan publik akan selalu berkaitan erat dengan masyarakat sehingga perlu partisipasi publik agar sebuah pelayan yang diciptakan dapat berjalan dengan baik. sama halnya dengan inovasi pelayanan Lukadesi di mana masyarakat memiliki peranan yang strategis. Ketika terjadi peristiwa kematian, maka masyarakat harus mengonfirmasi dan memberikan kabar kepada Kepala Dukuh setempat atau tokoh masyarakat. Selanjutnya Kepala Dukuh ataupun tokoh masyarakat setembat akan mendatangi masyarakat yang mengalami duka kematian selain membantu masyarakat yang berduka juga meminta dokumen untuk mengurus akta kematian seperti fotokopi KK, foto Kopi
KTP yang meninggal. Dokumen tersebut dikumpuklan dilengkapi dengan surat lelayu yang diterbitkan oleh tokoh setempat dan dokumen tersebut dibawa ke Pemerintah Desa untuk diproses lebuh lanjut.

Kedua, yakni melibatkan Pemerintah Desa setempat. Peranan Pemerintah Desa sangat penting dalam inovasi pelayanan Lukadesi ini. Pada perencanaanya setiap Pemerintah Desa yang ada di Kabupaten Sleman diwajibkan untuk membentuk petugas registrasi kependudukan desa. Petugas tersebut menjadi perwakilan desab yang bertanggungjawab atas tindak lanjut dari dokumen yang diserahkan dari padukuhan ke tingkat desa. Setelah dokumen tersebut diberikan ke Pemerintah Desa maka petugas registrasi kependudukan desa menindaklanjuti dokumen tersebut dengan mengirimkan dokumen secara cepat dengan menfotonya dan dikirimkan melalui aplikasi SIDAMPAK yang dikelola oleh Pemerintah Daerah. Oleh karenanya dokumen fisik akan dikirimkan oleh petugas registrasi kependudukan desa dikemudian hari asalkan dokumen yang asli cukup difoto saja. Setelah itu dari pihak desa menunggu konfirmasi dari Dinas setempat sampai dokumen tersebut dinyatakan memenuhi dan lengkap.

Ketiga, ialah peran utama dari Pemerintah Daerah yakni melalui Dinas Kependudukan dan Pencatatan Sipil Kabupaten Sleman. Disdukcapil Sleman akan memverivikasi dokumen permintaan yang diminta oleh Desa secara hati-hati. Menerbitkan surat kutipan akta kematian sama halnya dengan mengeluarkan produk hokum sehingga harus jelas siapa yang melaporkan dan untuk tujuan apa. Setelah 
dokumen tersebut dinyatakan memenuhi dan lengkap maka Dinas Kependudukan dan Pencatatan Sipil akan menerbitkan surat kematian pada hari kerja. Oleh karenanya ketika kmematianya terjadi di hari libur, maka penerbitan kutipan akta kematian akan dilakukan pada hari kerja dan diserahkan oleh petugas ketiga acara tahlilan kematian. Oleh karenanya pelayanan ini dapat dikatakan sehari bisa terbit dan ini menjadi pelayanan di bidang administrasi kematian tercepat yang ada di Indonesia. Melaui Lukadesi masyarakat sangat mersepon dengan sangat baik sehingga hadirnya inovasi ini memudahkan urusan masyarakat yang berduka.

\section{KESIMPULAN}

Berdasarkan uraian di atas maka dapat ditarik kesimpulan bahwa gerakan masyarakat tertib administrasi kependudukan dalam konsep inovasi pelayan publik Lukadesi cukup berhasil diterapkan. Tingginya partisipasi masyarakat menjadi bukti bahwa inovasi gerakan tertib administrasi kependudukan memiliki sumbangsih yang sangat besar dalam memperbaiki data kependudukan yang ada di database. Pada konsep tahapan teori yang kemukakan oleh De Jong dan Den Hartog maka inovasi ini telah memenuhi tahapan ataupun proses dengan sangat baik, mulai dari tahapan melihat kesempatan, mengeluarkan ide, mengkaji ide, dam implementasi.

Oleh karenanya karena keempat komponen dari teori yang diutarakan oleh De Jong dan Den Hartog sudah terpenuhi maka inovasi pelayanan Lukadesi ini sudah dapat dikatakan berjalan secara maksimal. sehingga memiliki dampak positif bagi pemerintah dan masyarakat.
Selama empat komponen tahapan tersebut telah dilewati dengan baik, maka hasil yang didapatkan juga menjadi lebih maksimal. terkait rekomendasi, peneliti memberikan saran agar inovasi tersebut diadopsi oleh pemerintah daerah lainya di dalam menciptakan masyarakat yang sadar administrasi kependudukan khususnya dibidang kematian.

\section{DAFTAR PUSTAKA}

Anggraeny, C. (2013). Inovasi Pelayanan Kesehatan dalam Meningkatkan Kualitas Pelayanan di Puskesmas Jagir Kota Surabaya. Jurnal Kebijakan Publik dan Manajemen Publik, 1(1).

Ariyani, A., Mindarti, L. I., \& Nuh, M. (2016). Inovasi Pelayanan Publik (Studi pada Pelayanan Kesehatan Melalui Program Gebrakan Suami Siaga di Puskesmas Gucialit Kabupaten Lumajang). Jurnal Ilmiah Administrasi Publik, 2(1)

Djamrut, D. E. (2015). Inovasi Pelayanan Publik Di Kecamatan Sungai Kunjang Kota Samarinda. Universitas Mulawarman, Samarinda. Hal, 1472-1486.

Dwidowidjoto, R, N. (2004). Kebijakan Publik: formulasi, Implementasi, dan Evaluasi. Jakarta: PT Elex Media Komputindo Kelompok Gramedia.

Febrian, R. A. (2016). Collaborative Governance Dalam Pembangunan Kawasan Perdesaan (Tinjauan Konsep Dan Regulasi). Wedana: Jurnal Kajian Pemerintahan, Politik Dan Birokrasi, 2(2), 200-208. 
Hisbani, N. A., Karim, M., \& Malik, I. (2017). Penerapan Inovasi Pelayanan Publik Di Dinas Kependudukan Dan Catatan Sipil Kabupaten Enrekang. Kolaborasi Jurnal Administrasi Publik, 1(3).

Masdy, N.A., Haerani, Siti., Alam, A.S. (2017). Peran Pemerintah Daerah Terhadap Pemberdayaan Pemuda Dalam Pengembangan Sektor Pariwisata Di Kabupaten Barru (Pantai Ujung Batu). Jurnal Analisis Seri-seri Ilmu Sosial, 6(1), 84-91.

Nugroho, H. S. (2019). Government Globalization As An Public Service Innovation In Wukirsari Village Sleman Regency. Prosiding ICOGISS 2019, 362-372.

Peyusinta, T. M., \& Setyawan, D. (2019). Inovasi Piket Malam Dalam Meningkatkan Kinerja Pelayanan Publik. JISIP Jurnal Ilmu Sosial Dan Ilmu Politik, 7(1).

Putra, R. M. D. (2018). Inovasi Pelayanan Publik Di Era Disrupsi (Studi Tentang Keberlanjutan Inovasi EHealth Di Kota Surabaya). Jurnal kebijakan dan Manajemen Publik, 6(2)

Rogers, EM (2003). Difussion of Innovation $5^{\text {th }}$ Edition, Free Press. New York

Ulfa, L. M. (2018). Collaborative Governance Dalam Penyediaan Ruang Terbuka Hijau (RTH) Taman Kota Di Surabaya (Doctoral dissertation, Universitas Airlangga).

Wibowo, I. T. (2019). Proses Difusi Inovasi Program Sakti (Studi Kasus Proses Difusi Inovasi
Program Sistem Aplikasi Keuangan Tingkat Instansi (SAKTI) Ditjen Perbendaharaan di DI Yogyakarta Tahun 2018). Indonesian Treasury Review: Jurnal Perbendaharaan, Keuangan Negara dan Kebijakan Publik, 4(4), 323-337.

Wulandari, Dewi., Unde, A. Alimuddin., Fatima, Jeanny Maria. (2017). Kemampuan Adaptasi Integrasi Pedagang Jawa Dengan Pedagang Lokal Pasar Tradisional Di Kota Makassar. Jurnal Analisis Seri-seri Ilmu Sosial, 6(1), 65-71.

Peraturan Menteri Pendayagunaan Aparatur Negara dan Reformasi Birokrasi Nomor 9 Tahun 2015 tentang Inovasi Pelayanan Publik

Lukadesi Untuk Masyarakat Sleman.

Diakses di

https://dukcapil.slemankab.go.id/lu kadesi-untuk-masyarakatsleman.stm pada 5 April 2020

Pukul 08.00 WIB

Batola Pelajari Pelayanan Lukadesi Sleman. Diakses di https://kalsel.antaranews.com/berit a/128235/batola-pelajaripelayanan-lukadesi-sleman https://v7.baritokualakab.go.id/?p $=7069$ pada 5 April Pukul 8.45 WIB

Pembuatan Akta Kelahiran dan Kematian Dipermudah Diakses di

https://www.suaramerdeka.com/ne ws/baca/125334/pembuatan-aktakelahiran-dan-kematiandipermudah pada 5 April 2020 pukul $10.00 \mathrm{WIB}$

Sleman Dukung Gerakan Indonesia Sadar Administrasi. Diakses di http://infopublik.id/kategori/nusant ara/295877/sleman-dukung- 
i. NAKHODA:

JURNAL

ILMU PEMERINTAHAN
NAKHODA: JURNAL ILMU PEMERINTAHAN

Edisi Januari-Juni Tahun 2020 Volume: 19 Nomor: 1

ISSN : 1829-5827 | E-ISSN : 2656-5277

DOI : https://doi.org/10.35967/jipn

https://nakhoda.ejournal.unri.ac.id/index.php/JIPN

gerakan-indonesia-sadar-

administrasi? show = pada 6 April

2020 pukul 11.00 WIB 